\title{
Vestibulární migréna
}

\author{
MUDr. Lukáš Martinkovič, doc. MUDr. Jaroslav Jeřábek, CSc. \\ Neuro-otologické centrum FN Motol, Praha \\ Neurologická klinika 2. LF UK a FN Motol, Praha
}

\begin{abstract}
Vestibulární migréna je klinická jednotka užívaná k popisu paroxyzmálních vestibulárních obtiží asociovaných s migrénou. Jedná se o častou příčinu epizodického vertiga, nicméně v praxi o nepř́liš známou diagnózu. Vyskytuje se ve všech věkových kategoriích, převažuje u žen. Jedná se o heterogenní onemocnění, přičemž neexistuje žádný test potvrzující její diagnózu. V rámci diferenciálně diagnostické rozvahy je třeba vyloučit zejména Ménièrovu chorobu, benigní paroxyzmální polohovou závrat' (BPPV) či cévní onemocnění v zadní jámě lební. Mezi léčebné postupy patři akutní symptomatická péče pomocí analgetik a antiemetik. Dle závažnosti, četnosti a trvání obtižź se dále uplatňuje profylaktická terapie. Př́istup je vždy individuální dle komorbidit pacienta.
\end{abstract}

Klíčová slova: vestibulární migréna, migréna, BPPV, Ménièrova choroba, ischemická CMP.

\section{Vestibular migraine}

Vestibular migraine is a clinical entity used to describe paroxysmal vestibular disorders associated with migraine. It is a common cause of episodic vertigo, but the diagnosis is not well known in clinical practice. It occurs in all age categories, predominant in women. It is a heterogeneous disease and there is no definitive test to confirm its diagnosis. Ménière's disease, benign paroxysmal positional vertigo (BPPV) or vascular diseases in the posterior fossa should be excluded within differential diagnosis. Antiemetics and analgesics are administered as acute symptomatic therapy. Depending on the severity, frequency and duration of clinical symptoms, prophylactic therapy is also used. The approach is always individual, according to the patient's comorbidities.

Key words: vestibular migraine, migraine, BPPV, Ménière's disease, ischemic stroke.

\section{Úvod}

Vestibulární migréna je klinická jednotka uživaná k popisu paroxyzmálních (epizodických) vestibulárních obtiží asociovaných s migrénou. Spojení vestibulárních obtíži a migrenózní bolesti hlavy je v literatuře zaznamenáno již v 19. století, nicméně samostatnou jednotkou se stává až v posledních dekádách. V současnosti je vestibulární migréna součástí klasifikace mezinárodní společnosti pro bolest hlavy (International Headache Society, IHS).

Prevalence vestibulární migrény není přesně známa. Dle populačních studií je odhadovaná celoživotní prevalence 1\% (Neuhauser et al., 2006). Ačkoliv se literárně uvádí, že se jedná o velmi časté onemocnění, tak dle epidemiologických studií jen $20 \%$ pacientů se zvažovanou vestibulární migrénou splnilo indikační kritéria (Furman et al., 2013). V 60-83\% postižených převažují ženy, podobně jako u migrény (Neuhauser et al., 2006). Vestibulární migréna je častěji diagnostikována u dětí než dospělých. Průměrný věk u dospělých je 40 let (Neuhauser et al., 2006).

Řada klinických prací uvádí vysokou prevalenci vestibulárních príznaků u pacientů s migrénou. Polovina až²/3 pacientů s migrénou trpí kinetózami (Murdin et al., 2015). U pacientů s migrénou, v období bez záchvatů, jsou v 53 až 66\% prípadư popisovány vestibulární a okulomotorické príznaky, jako spontánní, polohový, pohledový nystagmus, abnormální vestibulookulární reflex a další (Furman et al., 2013). U pacientů léčených pro vertigo je dle různých prací uváděna prevalence migrény v rozmezí 38 až 87\%, ve srovnání s 10 až
24\% u kontrolní skupiny (Cha et al., 2009). Analogií vestibulární migrény v dětském věku může být benigní paroxyzmální vertigo. Dlouhodobé sledování dětí s touto problematikou ukazuje, že většina z nich v budoucnu rozvine migrénu.

\section{Patofyziologie}

Patofyziologické mechanismy vestibulární migrény nejsou přesně známy, předpokládá se však heterogenní etiologie.

\section{Migrenózní aura}

U některých pacientů může vestibulární symptomatika představovat typickou migrenózní auru. Mechanismem vzniku se rozumí vina neuronální a gliové depolarizace. Mưže se jednat o její šiřrení v rámci kmene, či projekce

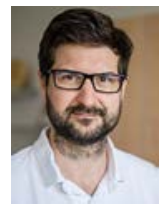

KORESPONDENČNÍ ADRESA AUTORA: MUDr. Lukáš Martinkovič, Lukas.Martinkovic@fnmotol.cz Neuro-otologické centrum FN Motol,

Neurologická klinika 2. LF UKa FN Motol, V Úvalu 84, 15000 Praha 5

Cit. zkr: Neurol. praxi 2020; 21(6): 460-463

Článek přijat redakcí: 25. 5. 2020

Článek príijat k publikaci: 9. 7. 2020 
z parietální kưry směrem do vestibulárních jader (Furman et al., 2003)

\section{Trigeminovaskulární systém}

Trigeminovaskulární systém se sestává z pseudounipolárních senzorických neuronů pocházejících z trigeminálního ganglia a horních krčních dorzálních kořenů. Tyto senzorické neurony inervují velké mozkové cévy, piální cévy, dura mater, velké žilní splavy. Stimulace trigeminálního ganglia vede k vazodilataci a uvolňování vazoaktivních neuropeptidů (napr. substance P). Existují také vestibulární receptory, které jsou specifické alespoň pro jeden z těchto peptidů např. calcitonin gene-related peptid.

\section{Senzorická citlivost}

Pacienti s migrénou mají sníženou prahovou hodnotu pro četné smyslové podněty, včetně pohybu, světla, zvuku, dotykových podnětů a pachů. S větší pravděpodobností vykazují subklinické vestibulocerebelární abnormality (Furman et al., 2003).

\section{Ischemie související s migrénou}

Ischemie vnitřního ucha indukovaná migrénou může vést k poškození kochley či labyrintu. Migréna s aurou se dále jeví jako rizikový faktor pro ischemickou cévní mozkovou príhodu, pravděpodobně v souvislosti se vznikem vazospasmů (Radtke et al., 2002).

\section{Endolymfatický hydrops}

Záchvaty Ménièrovy choroby podmíněné endolymfatickým hydropsem a vestibulární migrény mají podobný charakter obtižíi délku trvání a mohou být, zejména v počátcích onemocnění, klinicky obtížně odlišitelné.

\section{Benigní paroxyzmální polohová závrat' (BPPV)}

Migréna je také spojována s benigním polohovým vertigem (Brevern et al., 2004). Migrenózní cefalea byla pozorována třikrát častěji u pacientů s idiopatickým BPPV ve srovnání s pacienty se sekundárním BPPV. Zároveň byla prítomna u více než poloviny pacientů, u nichž bylo pozorováno BPPV do 50 let věku (Ishiyama et al., 2000).

\section{Klinické příznaky}

Většina pacientů s vestibulární migrénou má migrenózní bolest hlavy a epizodické ves- tibulární príznaky bez dalších neurologických přiznaků.

\section{Neprovokovaná závrat}

Jedná se o epizody závratě, kdy pacient vnímá pocit pohybu vlastního těla či pohybu okolí vǔči vlastnímu tělu. Nejčastěji je popisována rotační závrat, dále pacienti udávají tah ze strany na stranu či pocit houpání jako na lodi. Závrativé obtíže jsou často zhoršeny změnami polohy, občas jsou změnou polohy hlavy vyvolány (Radtke et al., 2011). Přetrvávání obtiží v rámci hodin po změně polohy hlavy naznačuje spíše vestibulární migrénu než BPPV. Mezi další často udávané symptomy patři pocit nestability, vizuálně vyvolaná závrat' (např̀ pohyb dopravních prostředků) a podobně (Cohen et al., 2011). Nystagmus je během epizod vestibulární migrény obvykle prítomen. Může být spontánní, pohledový, polohový. Mưže mít charakter periferního či centrálního původu (Furman et al., 2013).

\section{Bolest hlavy}

Zatímco závratě se mohou objevit s bolestí hlavy nebo bez ní, migrenózní cefalea je asociována s některou z vestibulárních epizod u 50 až 94\% pacientů (Radtke et al., 2011). Závrat’ se může objevit kdykoliv při bolesti hlavy, málo pacientů však udává závrat jako typickou auru (trvající 5 až 60 minut) předcházející bolesti hlavy (Eggers et al., 2011). Mezi provokující faktory patří spánková deprivace, potraviny, stres. Tyto faktory hrají stejnou roli jako u jiných forem migrenózní cefaley (Furman et al., 2013). Zrakové či pohybové spouštěče (zářivky, sledování vlaků, otevřená prostranství) mohou být významné u některých pacientů (Cohen et al., 2011)

\section{Doprovodné príznaky}

Často se vyskytuje foto či fonofobie, nauzea, vomitus. Tyto príznaky mohou být ale vyvolány i sekundárně závratí (Radtke et al., 2011).

\section{Sluchové príźnaky}

U 2/3 pacientů se vyskytuje tinnitus (uni či bilaterální) a subjektivní zhoršení sluchu. Jejich přítomnost neumožňuje rozlišit Ménièrovu chorobu od vestibulární migrény (Neff et al., 2012). Přestože u migrény byla popsána jak náhlá, tak fluktuující nízkofrekvenční ztráta sluchu, prevalence ztráty sluchu u pacientů s migrénou je nízká (Harno et al., 2003). Progresivní nebo fluktuující nízko až středně frekvenční senzorineurální ztráta sluchu spojená s epizodickým vertigem je typičtější pro Ménièrovu chorobu (Lopez-Escamez et al., 2015).

\section{Délka trvání obtíži}

Trvání obtíži je variabilní, většinou minuty až hodiny. U $10 \%$ osob se jedná o vteřiny, u 30\% minuty, u 30\% hodiny a u zbylých 30\% osob obtíže trvají až několik dní (Olesen, 2018). Vzácně obtíže trvají déle než 72 hodin (Versino et al. 2003). Vzácně jsou epizody popisovány několikrát denně, častěji však jen několikrát ročně (Brantberg et al., 2009).

\section{Diagnostická kritéria}

Při absenci specifického diagnostického testu je vestibulární migréna především diagnóza založená na klinických přiznacích s vyloučením ostatních možných príčin vestibulárních obtiží (= diagnosa per exclusionem).V současnosti jsou nejrozšiřenější diagnostická kritéria stanovena společně Bárányho společností a International Headache Society, zahrnutá do Mezinárodní klasifikace bolestí hlavy (Lempert et al., 2012; Olesen, 2018).

\begin{tabular}{|c|}
\hline $\begin{array}{l}\text { Diagnostická kritéria pro vestibulární migrénu } \\
\text { (dle Bárányho společnosti a zahrnuto } \\
\text { v Mezinárodní klasifikaci pro bolesti hlavy) }\end{array}$ \\
\hline $\begin{array}{l}\text { 1. Alespoň pět epizod vestibulárních symptomů } \\
\text { střední nebo vysoké intenzity, trvajících } 5 \text { minut } \\
\text { až } 72 \text { hodin }\end{array}$ \\
\hline $\begin{array}{l}\text { 2. Migréna s aurou/bez aury v současné či dřívější } \\
\text { anamnéze }\end{array}$ \\
\hline $\begin{array}{l}\text { 3. Alespoň } 50 \% \text { vestibulárních epizod je spojeno } \\
\text { s alespoň jedním z následujících tří kritérií } \\
\text { pro migrenózní bolest hlavy: } \\
\text { bolest hlavy s alespoň dvěma z následujících } \\
\text { charakteristik (jednostranná, pulzující, střední } \\
\text { nebo vysoká intenzita bolesti, zhoršení běžnou } \\
\text { fyzickou aktivitou) } \\
\text { fotofobie a fonofobie } \\
\text { zraková aura }\end{array}$ \\
\hline 4. Příznaky nesplňující jinou diagnózou \\
\hline
\end{tabular}

\begin{tabular}{|l|}
\hline $\begin{array}{l}\text { Diagnostická kritéria pro pravděpodobnou } \\
\text { vestibulární migrénu (dle Bárányho společnosti) }\end{array}$ \\
\hline 1. Alespoň pět epizod vestibulárních symptomů \\
střední nebo vysoké intenzity, trvajících 5 minut \\
až 72 hodin \\
\hline $\begin{array}{l}\text { 2. Pouze jedno kritérium z bodu 2. a } 3 \text {. } \\
\text { pro vestibulární migrénu (anamnéza migrény } \\
\text { nebo přítomnost migrény během epizody) }\end{array}$ \\
\hline 3. Př́znaky nesplňující jinou diagnózou \\
\hline
\end{tabular}

\section{Diferenciální diagnóza}

Diferenciální diagnóza pacientů se závratěmi je rozsáhlá. Mezi nejčastější onemocnění patř́ jiné varianty migrény, Ménièrova choroba, tranzitorní ischemické ataky/ischemické cévní mozkové príhody z vertebrobazilárního povodí. 
- Migréna s kmenovou aurou vyžaduje dva nebo více fokálních kmenových příznaků (v rámci aury) trvajících 5 až 60 minut předcházejících migrenózní bolest hlavy. Ačkoliv závrat' patří mezi nejčastější príźnaky migrény s kmenovou aurou, pouze malá část pacientů s vestibulární migrénou splní kritéria pro migrénu s kmenovou aurou (Eggers et al., 2011).

- Ménièrovu chorobu, dle populačních studií desetkrát méně častější než vestibulární migréna, je poměrně složité rozeznat od vestibulární migrény vzhledem k překrývajícím se klinickým projevům (Lopez-Escamez et al., 2015). Príznaky, v podobě pocitu zalehlého ucha, tinnitu, ztráty sluchu (předcházejících atace nebo při nástupu ataky), svědčí pro Ménièrovu chorobu, stejně tak se ale mohou vyskytnout u vestibulární migrény (Neffet al., 2012). Audiometricky verifikovaná, progredující či fluktuující (nízko až středně frekvenční) ztráta sluchu je nejdůležitější pro identifikaci Ménièrovy choroby. Vzácně mohou být audiologické symptomy minoritní či vůbec žádné. Záchvaty vertiga asociované s bolestí hlavy, fotofobií nebo zrakovou aurou jsou prítomny u $45 \%$ pacientů s Ménièrovou chorobou (Radtke et al., 2002). Ménièrova choroba a migréna však také mohou být vzájemnými komorbiditami (Eggers et al., 2014).

- Kmenová ischemie obvykle vyvolává kromě závrati také další príiznaky (poruchu citlivosti, parézu, diplopii, dysartrii, dysfagii). Zvláště u starších či cévně rizikových pacientů je na tuto diagnózu nutno pomýšlet, pokud dřive neudávali závrativé obtíže. Klíčové je vyšetření MRI, zejména využití difuzně vážených sekvencí (DWI = Diffusion Weighted Imaging), které potvrdí ischemii již v časném stadiu. U tranzitorních ischemických atak může být MRI negativní.

\section{- Benigní paroxyzmální polohové vertigo} (BPPV) je nejčastější prričinou epizodické závrati. Mezi př́znaky, svědčíci pro diagnózu vestibulární migrény spiše než BPPV, patří prítomnost migrenózních bolestí během závratí, delší trvání závrativých obtízí (spíše

\section{LITERATURA}

1. Brantberg K, Trees N, Baloh RW. Migraine-associated vertigo. Acta Oto-laryngol 2009; 125(3): 276-279.

2. Brevern M von, Radtke A, Clarke AH, Lempert T. Migrainous vertigo presenting a episodic positional vertigo. Neurology několik minut až hodin, než sekundy či minuty typické pro BPPV), mladší věk nástupu a netypický polohový nystagmus. BPPV a vestibulární migréna mohou být společné komorbidity.

- V prípadě vestibulární paroxyzmie se jedná o velmi krátké (jedna až několik vteřin), časté (až několikrát denně) epizody vertiga bez př́znaků migrény. Nejčastěji se připisuje neurovaskulárnímu konfliktu n. vestibulocochlearis s arteria cerebelli posterior inferior.

- Perzistentní posturálně-percepční závrat' (Persistent Postural-Perceptual Dizziness, PPPD) označuje syndrom funkční nerotační závratě a poruchy stability, který kombinuje základní rysy dřive popsaných syndromů, jako je fobické posturální vertigo a chronická subjektivní závrat' (Staab et al., 2017). Na rozdíl od vestibulární migrény způsobuje PPPD spíše chronickou, kolísavou nerotační závrat než spontánně vzniklé epizodické vertigo (Eggers et al., 2014).

\section{Léčba}

\section{Symptomatická léčba záchvatu}

- Léky potlačující akutní obtíže, zejména vegetativní doprovod. Mezi tato léčiva patři benzodiazepiny (diazepam, alprazolam, bromazepam), antiemetika (thiethylperazin, metoklopramid, ondansetron) a antihistaminika (cinnarizin), z nichž některé lze podávat rektálně, pokud nelze užít perorálně.

- Triptany se běžně nepoužívají pro akutní záchvaty vestibulární migrény, Ize je však zvážit, když vertigo působí jako migrenózní aura - triptany se pak užijí až po odeznění aury. Mezi nejčastěji užívané patří sumatriptan, zolmitriptan, eletriptan, naratriptan. Všechny tyto preparáty jsou dostupné ve formě tabletové, sumatriptan je k dispozici i ve formě nosního spreje.

\section{Profylaktická léčba}

- Režimová opatření, zejména vyvarování se spouštěcích mechanismů.

2004; 62(3): 469-472.

3. Cha Y-H, Lee H, Santell LS, Baloh RW. Association of benign recurrent vertigo and migraine in 208 patients. Cephalalgia Int J Headache 2009; 29(5): 550-555.
- Profylaktická léčba migrény může být vhodná pro pacienty s častými epizodami vestibulární migrény, zejména pokud není účinná akutní léčba. Indikace pro profylaktickou terapii je podobná, jako u jiné migrenózní bolesti hlavy, zohledňující frekvenci, délku trvání a charakter obtíží. Při léčbě epizodické závratě a bolesti hlavy používáme betablokátory, tricyklická antidepresiva nebo antiepileptika topiramát, valproát. V prípadě převládajících vestibulárních příznaků $\checkmark$ kombinaci s komorbiditami typu PPPD, úzkostí či depresí zvažujeme inhibitory zpětného vychytávání serotoninu a/nebo noradrenalinu (např. escitalopram, venlafaxin). Při průkazu vestibulární dysfunkce je možné vyzkoušet betahistin.

- Identifikace a léčba komorbidit je důležitá př̀ léčbě vestibulární migrény. Mezi běžné komorbidity patři BPPV, kinetóza, PPPD a úzkost. Komorbiditou může být i Ménièrova choroba (Eggers et al., 2014).

\section{Závěr}

Vestibulární migréna je termín používaný k popisu epizodického vertiga u pacientů s migrenózní cefaleou nebo jinými klinickými př́znaky migrény, jako je fotofobie, fonofobie, zraková aura apod. Vestibulární migréna je považována za častou př́činu epizodického vertiga. Vyskytuje se ve všech věkových kategoriích, převažuje u žen. Existují různé důkazy, že vestibulární systém je ovlivněn u pacientů s migrénou. Klinické a epidemiologické nálezy spolu se zvažovanými patofyziologickými mechanismy naznačují, že vestibulární migréna je heterogenní onemocnění. Neexistují žádné testy potvrzující vestibulární migrénu. Ta je diagnostikována na základě klinických projevů při vyloučení jiné příčiny obtíží, zejména BPPV, Ménièrovy choroby a cévních onemocnění v zadní jámě lební. Léčebné postupy zahrnují akutní symptomatickou léčbu zejména pomocí analgetik (triptany) a antiemetik. Dle závažnosti, četnosti a trvání obtíži se dále uplatňuje profylaktická terapie. Přístup je vždy individuální dle komorbidit pacienta.

4. Cohen JM, Bigal ME, Newman LC. Migraine and vestibular symptoms - identifying clinical features that predict "vestibular migraine". Headache 2011; 51(9): 1393-1397. 5. Eggers SDZ, Neff BA, Shepard NT, Staab JP. Comorbidities 
in vestibular migraine. J Vestib Res Equilib Orientat 2014; 24(5-6): 387-395.

6. Eggers SDZ, Staab JP, Neff BA, Goulson AM, Carlson ML, Shepard NT. Investigation of the coherence of definite and probable vestibular migraine as distinct clinical entities. Otology Neurotol Official Publ Am Otological Soc Am Neurotol Soc European Acad Otology Neurotol 2011; 32(7): 1144-1151. 7. Furman JM, Marcus DA, Balaban CD. Migrainous vertigo: development of a pathogenetic model and structured diagnostic interview. Curr Opin Neurol 2003; 16(1): 5-13.

8. Furman JM, Marcus DA, Balaban CD. Vestibular migraine: clinical aspects and pathophysiology. Lancet Neurology 2013; 12(7): 706-715.

9. Harno H, Hirvonen T, Kaunisto MA, Aalto H, Levo H, Isotalo E, Kallela M, Kaprio J, Palotie A, Wessman M, Farkkila M. Subclinical vestibulocerebellar dysfunction in migraine with and without aura. Neurology 2003; 61(12): 1748-1752. 10. Ishiyama A, Jacobson KM, Baloh RW. Migraine and Benign Positional Vertigo. Ann Otology Rhinology Laryngology 2000; 109(4): 377-380.

11. Lempert T, Neuhauser H. Epidemiology of vertigo, migraine and vestibular migraine. J Neurol 2009; 256(3): 333-338.

12. Lempert T, Olesen J, Furman J, Waterston J, Seemungal B, Carey J, Bisdorff A, Versino M, Evers S, Newman-Toker D. Vestibular migraine: Diagnostic criteria. J Vestib Res 2012; 22(4): 167-172. 13. Lopez-Escamez JA, Carey J, Chung W-H, Goebel JA, Magnusson M, Mandalà M, Newman-Toker DA, Strupp M, Suzuki $M$,Trabalzini F, Bisdorff A. Diagnostic criteria for Menière's disease. J Vestib Res 2015; 25(1): 1-7.

14. Murdin L, Chamberlain F, Cheema S, Arshad Q, Gresty MA, Golding JF, Bronstein A. Motion sickness in migraine and vestibular disorders. J Neurology Neurosurg Psychiatry 2015; 86(5): 585

15. Neff BA, Staab JP, Eggers SD, Carlson ML, Schmitt WR, Abel KMV, Worthington DK, Beatty CW, Driscoll CL, Shepard NT. Auditory and vestibular symptoms and chronic subjective dizziness in patients with Ménière's disease, vestibular migraine, and Ménière's disease with concomitant vestibular migraine. Otology Neurotol Official Publ Am Otological Soc Am Neurotol Soc European Acad Otology Neurotol 2012; 33(7): 1235-1244.
16. Neuhauser HK, Radtke A, Brevern M von, Feldmann M Lezius F, Ziese T, Lempert T. Migrainous vertigo. Neurology 2006; 67(6): 1028-1033.

17. Olesen J. Headache Classification Committee of the International Headache Society (IHS) The International Classification of Headache Disorders, $3^{\text {rd }}$ edition. Cephalalgia 2018; 38(1): 1-211.

18. Radtke A, Lempert T, Gresty MA, Brookes GB, Bronstein AM, Neuhauser H. Migraine and Meniere's disease: Is there a link? Neurology 2002; 59(11): 1700-1704.

19. Radtke A, Neuhauser $H$, Brevern M von, Hottenrott T, Lempert T. Vestibular migraine - validity of clinical diagnostic criteria. Cephalalgia Int J Headache 2011; 31(8): 906-913. 20. Staab JP, Eckhardt-Henn A, Horii A, Jacob R, Strupp M Brandt T, Bronstein A. Diagnostic criteria for persistent postural-perceptual dizziness (PPPD): Consensus document of the committee for the Classification of Vestibular Disorders of the Barany Society. J Vestib Res 2017; Preprint(Preprint): 1-18. 21. Versino M, Sances G, Anghileri E, Colnaghi S, Albizzati C, Bono G, Cosi V. Dizziness and migraine: a causal relationship? Funct Neurol 2003; 18(2): 97-101. 